\title{
River Floodplain 1D/2D Hydraulic Modelling Combined with Recent LiDAR DTM Technology
}

\author{
Slobodan KOLAKOVIĆ, Srđan KOLAKOVIĆ*, Julius FABIAN, Goran JEFTENIĆ, Slaviša TRAJKOVIĆ
}

\begin{abstract}
The study presents problem of floods management for lowland rivers and provides solution for such complex task. The paper aims to elaborate a methodology for flood management model on large lowland rivers using precision digital terrain models (DTM) and combined 1D/2D unsteady flow model. The river Danube on the territory of Serbia was used with its tributaries for the development of the model. The length of the hydraulic model is $715 \mathrm{~km}$ and the achieved accuracy of the model, by comparing the calculated and observed levels on 10 water stations, is below $10 \mathrm{~cm}$. Combined 1D/2D HEC-RAS model is adjusted by making use of the resulting high-resolution input. The ability of the combined 1D/2D model, based mainly on the high-accuracy input data, provides an accurate estimate of flood wave propagation. The result of this paper is a defined methodology providing sufficient accuracy to the hydraulic model of flood wave propagation in case of large lowland rivers, requiring acceptable short calculation time. Also, the methodology to specify relevant flood stage (design flood) which is used to determine levee crest elevation is developed in this paper.
\end{abstract}

Keywords: 1D/2D hydraulic model; DTM; flood management

\section{INTRODUCTION}

The starting point when considering floods in large lowland catchments is that in fact flood damages are not caused by the river, but by anthropogenic impacts caused by people who inhibited river and lake banks, alluvial plains, in particular in search for potable water and fertilewet land which would provide opportunity for farming and fishing. Subsequent development of trading has made streams main trade routes even though to a lesser extent nowadays. Therefore, river banks have become urbanized areas, where coastal settlements and towns were developed and keep developing into main commercial and economic centres in a number of countries.

In the $21^{\text {st }}$ century anthropogenic impacts on surface water management have been the subject of several studies, focusing on the effects of climate and land-use changes on frequency and magnitude of floods $[5,9,11,14,17,24,28$ 31].

Data provided by the Brussels University Institute of Health and Society [12] show that China, the USA, Indonesia, the Philippines and India are the countries most affected by natural disasters in recent decades. In the given period of 2003-2015 the number of hydrological disasters took by far the largest share $(50.6 \%)$ in natural disaster presented in Fig. 1. Floods caused by natural disasters killed on average 106 thousand people a year worldwide, whereas another 199.2 million people were affected in various ways. The estimated economic loss in the given period equals approximately US $\$ 159$ billion a year.

Hydrological disasters (primarily floods) were the most frequent in all regions [13]. If we analyse only Europe for the same period floods were the most reported disaster in Europe with some significant differences between regions (Fig. 2). The number of floods in Northern and Western Europe have annual average of 1.8 and 2.1, respectively for given period of 2006-2015. In Eastern and Southern Europe, floods are much more common, with annual averages of 7.3 and 8.6, respectively. In 2016, the trend continued [13].

The question asked after any such disastrous flood event must be: could it have been prevented? Or, at least mitigated? Is it not possible to give an early warning to people of the forthcoming events?

\subsection{Problem Statement with Existing Practice in Flood Management}

Human interventions have often intensified, rather than mitigated, flood risk in lowland environments $[8,16$, 26]. The "life space" of a stream thus becomes narrower with the stream increasing its water level in return. The bottleneck effect regarding levees is the result of the reduced area left to the stream for safe flood discharge. This is true for circumferential levees around cities, industrial areas and for levees protecting agricultural land along streams as well. The role of the last ones is particularly questionable because they are intended for protection of large areas of land which otherwise are capable of retaining significant amounts of flood discharge under natural conditions (that is, without levees) [3].

The man and the river have been struggling for ages and they still are. The construction of levees in the lower Danube through Slovakia, Hungary and Serbia started in the late seventeenth and early eighteenth centuries. The present flood defence lines along large streams (the Danube, the Tisa, the Sava, ...) in Central Europe were actually established in the early twentieth century. The principal strategy was to construct levees along the streams which were super elevated after every major flood. This is called "passive" flood defence in engineering practice. The most appropriate remark about the strategy was given by Nikola Mirkov (1890-1957), a Serbian water resource engineer who pioneered in the development of water resource engineering in the twentieth century.

"Today's levees are really impressive in comparison to the old ones but, again, they cannot be considered safe, they are just a little bit safer than the former ones". [19] This remark is unfortunately still true. It was followed by the disastrous 1941 and 1965 floods in the Danube basin, 1879 and 1970 floods in the Tisa basin [16] and the 2006 and 2014 floods in the Sava basin, which proved that the reconstructed old levees are "just a little bit safer than the former ones" despite the large investments in the levee upgrades in the late twentieth century. A new strategy based primarily on 
flood propagation management and scenario anticipation in order to mitigate the adverse effects of devastating floods has recently proven to be a must. This is also indicated in the Directive 2007/60/EC of the European Parliament and of the Council of $23^{\text {rd }}$ October 2007 on the assessment and management of flood risks (2007) based on two standpoints:
"Floods are natural phenomena which cannot be prevented."

"It is feasible and desirable to reduce the risk of adverse consequences, especially for human health and life, the environment, cultural heritage, economic activity and infrastructure associated with floods."

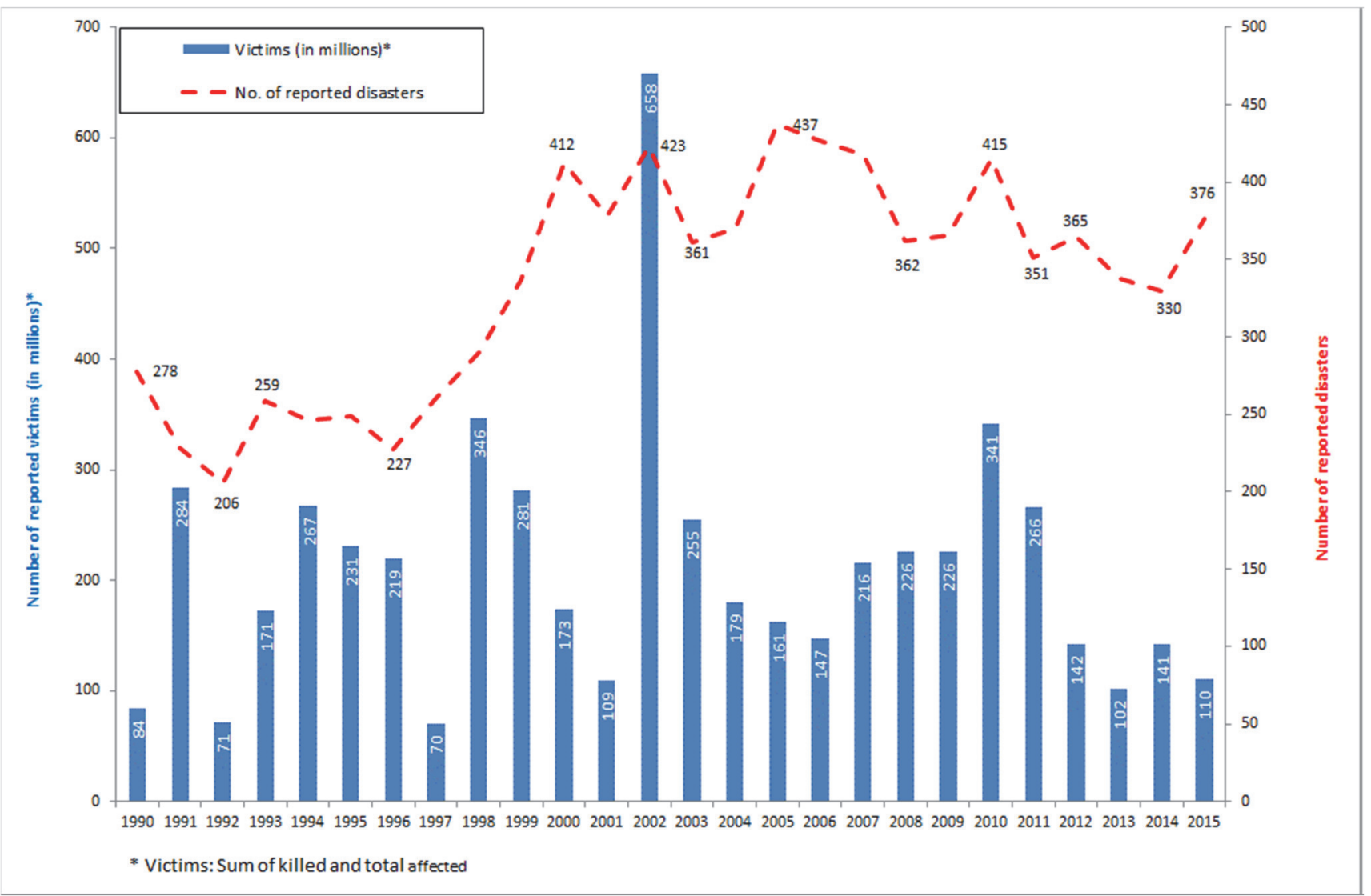

Figure 1 Summary of registered worldwide annual disasters and victims [12]

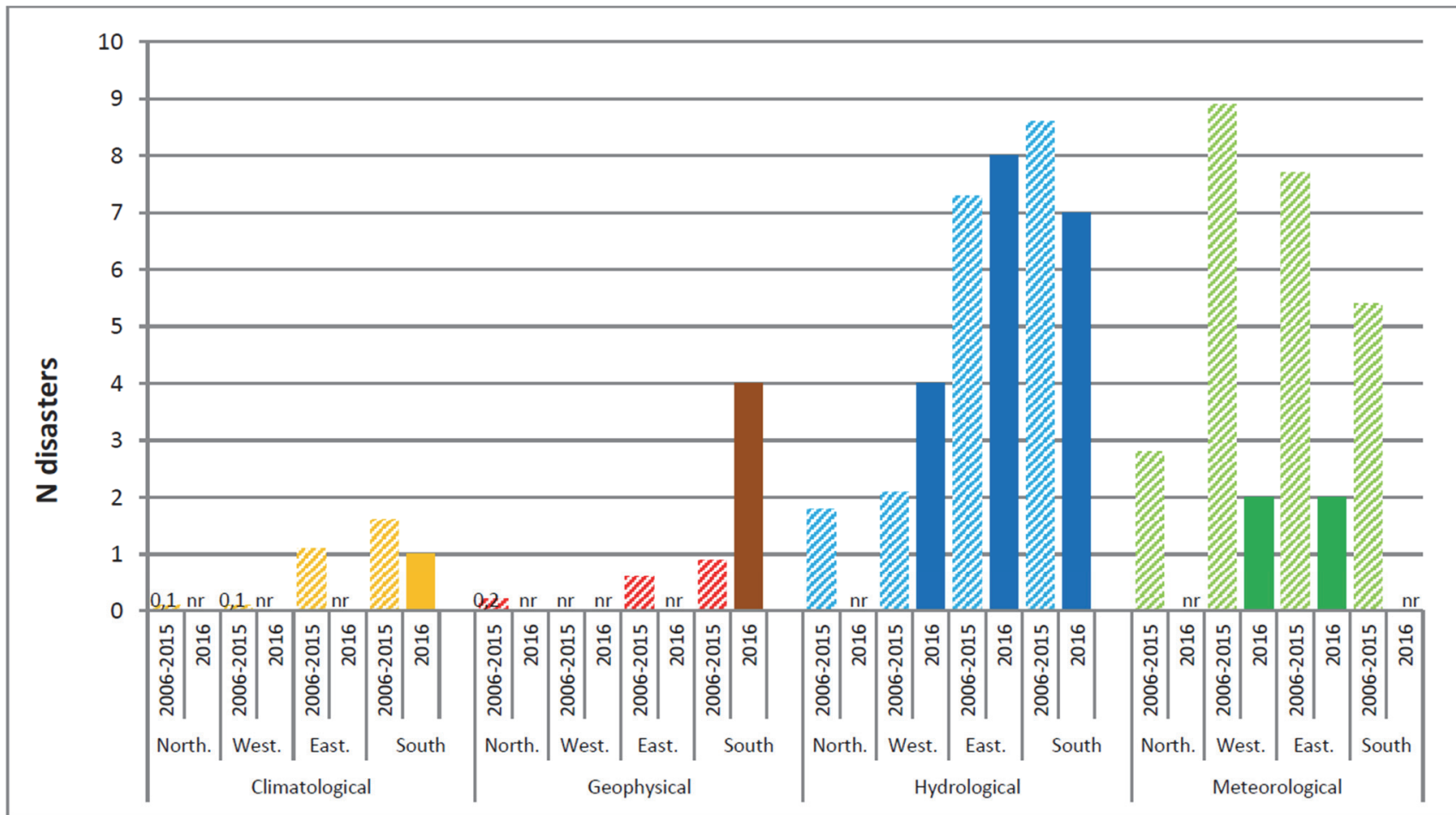


These indicate that tendencies in the concentration of investments in floodplains in certain parts of the world have started disputes on acceptable flood risk levels and the change in flood management policy. A need for closer integration of flood management and land development has emerged [3]. It is increasingly believed that floods can only be controlled to a certain extent and that there is no such thing as complete flood protection. The belief is well supported by the recent climate changes where the impact on floods is reflected in their increased frequency and peaks.

Any active and passive flood defence measures should be included in the process of land development in order to provide the required space in advance to be used in the future for flood protection. In engineering practice this means a challenge due to limited land resources and increasing human needs (dam constructions, storages, construction of barriers and drainage channels, industrial development, urban expansion, agricultural development, etc).

In the existing practice of large river flood defence strategies in Central Europe, all the attention is directed to the assessment of the $1 \%$ flood (declared as "design flood") using the method of annual maximum flow (statistical analysis of annual maximum flow). However flow parameters can show significant discrepancies from the parameters related to water levels. Hydrological changes in a stream can be more accurately monitored using time series. Analyses of time series data should be therefore upgraded, that is, additional values computed from the established hydraulic modelling should be incorporated into the already calculated values.

According to the previous, the increased interest of scientific and professional public for area of defence from floods appeared during last ten years. The main reason is the fact that floods intensified all over the world which is devastating in regard to human victims at the first place. Society acknowledged that floods can be controlled to the certain limit and that there is no absolute protection from floods. It is necessary to include integral management of floods with the aim to make maximum use of flood areas through minimum losses of human lives and material damages. Floods must be managed and it requires reliable numerical models.

\subsection{DTM Resolution Problem in Large Hydraulic Model Simulations}

Prerequisite for the accuracy of a hydraulic model is generation and use of precise detailed terrain models (DTM). Advanced geospatial technologies (Global Navigation Satellite System-GNSS), remote sensing (RS) and Geographic Information System (GIS) have allowed much faster and accurate acquisition of data, flood analyses and flood hazard mapping.

In the recent past an article by Bales et al. [4] provided a comprehensive approach to DTM generation using LiDAR (Light and Detection Ranging) scanning. In case of flood wave propagation simulation accuracy of $0.44 \mathrm{~m}$ (where the low to high water stage difference was $5.7 \mathrm{~m}$ ) was achieved for the $172 \mathrm{~km}$ along the North Carolina Tar River hydraulic model. The error divided by the stage difference results in relative error of $7.7 \%$, as declared in the article. In the results from this study the Danube River hydraulic model presented error of only $1.1 \%$ in relation to the stage difference range.

Airborne and terrestrial LiDAR survey data have been compared with 120 control points in recent research [25]. The results indicate mean error in the aerial and terrestrial surveys of 0.133 and $0.081 \mathrm{~m}$, respectively. It is interesting to note that the authors of the article declared that development of hydraulic models using LiDAR data presented in their article was one of the first attempts of the kind in the USA. Note that the development of the Tisa River hydraulic model based on LiDAR survey, accomplished with the Danube River boundary condition [16] started even earlier, in 2011.

Flood research at hydrological basin scale requires high-resolution data, particularly when using the robust hydrological models that have been developed recently. According to the USA Federal Emergency Management Agency (FEMA) information the National Digital Elevation Program (NDEP) sponsored by the National Enhanced Elevation Assessment (NEEA) was developed in the USA during 2011 and accomplished in December 2011. The NEEA initiative resulted in the development of a 3D terrain model (3D Elevation Program) of all flood inundations. Five quality levels (QL) of topographic data are identified, while the three highest quality ones need to be derived from LiDAR survey. The aim was to achieve a QL2 quality level (vertical root-mean-square error (RMSE) of $9.25 \mathrm{~cm}$ with rated point increment of $0.7 \mathrm{~m}$ ).

Turner et al. [25] suggested that using combination of 1D/2D flow model with DTM gained by airborne survey having point spacing of $5 \mathrm{~m}$ and accuracy of $\pm 25 \mathrm{~cm}$ is inappropriate, since in the case of the Boone Creek (North Carolina) study the DTM of the specified characteristics showed to be too coarse. Also in recent studies authors [27] recommend high-accuracy DTM. Their study provides spatial resolution of $1 \mathrm{~m}$ but only for the study area of 3.5 $\mathrm{km}$ river flow.

Methodology of coupled 1D/2D hydraulic models used in this research has come up in the last few years [1, $6,7,10]$; however it has been applied on the shorter river sections only.

As already mentioned, computer time of a simulation is as important as its accuracy. For example, according to Sampson et al. [21] in case of high-resolution models with accuracy of approximately $10 \mathrm{~cm}$ covering area of 0.11 $\mathrm{km}^{2}$ when exploiting hydraulic 2D model LISFLOOD-FP a single run of simulation requires over 10 computer hours! This is supported by the study of Meesuk et al. [18] performed by a 2D model on the area of $0.4 \mathrm{~km}^{2}$.

Shen et al. [22] also point out the same issue and suggest: "Limitations of existing computing resources further limit applications which require very detailed risk assessments or analyses based on large areas. There is an ongoing requirement for appropriate procedures to generate reliable computing schemes with significant number of elements that modern computers can handle."

However, 2D models are computationally heavy and data intensive, which can impose challenges for real-time flood forecasting [2].

The methodology presented in this article provided accuracy of the calculated results (compared to the measured) of $10 \mathrm{~cm}$ in the $715 \mathrm{~km}$ long model and DTM 
area of approximately $650 \mathrm{~km}^{2}$, with duration of a single simulation of only 2-3 hours.

The objective of the study in relation to the above presented issues was to establish a methodology for the development of a hydraulic model of flood wave propagation that can ensure sufficient accuracy with simulations short enough to serve their purpose. That is, simulations need to demonstrate the effects of various measures on flood wave mitigation and provide sufficient time for the proposed measures to be implemented. This particularly refers to rising the line of defence, opening and flooding of temporary floodwater retentions, etc. Evacuation time is also of great importance as well as the mitigation of adverse effects of an extreme flood wave.

There is a development of technologies for recording of the land from the air and program software packages $1 \mathrm{D} / 2 \mathrm{D}$ which simulate propagation of the flow wave relatively quick with sufficient accuracy, which is important for this study of hydraulic simulation on such large lowland river as the Danube is.

The main goal in this paper is to define methodology providing sufficient accuracy to the hydraulic model of flood wave propagation in case of large lowland rivers, requiring acceptable short calculation time. Furthermore, the methodology to specify relevant flood stage (design flood) which is used to determine levee crest elevation is developed as well.

\section{THE STUDY AREA}

The Danube is the biggest river of Central and Southeast Europe, belonging to the catchment of the Black Sea. Following the Volga, the Danube is the second river of the Europe region in terms of catchment area (817000 $\left.\mathrm{km}^{2}\right)$ and length $(2912 \mathrm{~km})$. Due to its geographic position, length and development of the surrounding countries, it represents traffic corridor of the highest importance in
Europe with pronounced international character connecting the Northern, Central and Southeastern countries of Europe. It is connected to the most significant European rivers by channels.

The Danube passes through Serbia in the length of 588 $\mathrm{km}$ having special importance for Belgrade, Novi Sad and other big cities and their industries (Fig. 3). The most significant rivers belonging to the Danube watershed (the Tisa, the Sava) bring vast amount of water to province Vojvodina, since the corresponding flood waves feed on quick snow melt in the Alps and Carpathian Mountains frequently followed by rains. Continental climate occasionally showing even subtropical character with extreme precipitation, change of moist and dry periods make Vojvodina a prominent part of Europe for water management potential. It is important to notice that to the end of the seventeenth century $35 \%$ of the Backa and Banat districts has been permanently endangered by high waters of the corresponding rivers.

The Danube sector covered by the hydraulic model from the Nera estuary (Danube $\mathrm{km} \mathrm{1075)}$ up to the Hungarian border (Danube km 1433) - has lowland character through Serbia. It should be noted that the Danube catchment area - modeled with its tributaries in Serbia from the location of Nera discharging into the Danube to the water gage station Bezdan (Danube $\mathrm{km}$ 1425,6 ) having length of $350 \mathrm{~km}$ with average width of the alluvial planes of $1 \mathrm{~km}$ - is about $350-400 \mathrm{~km}^{2}$. The complete length of the modeled water course of the Danube catchment in Serbia, including the tributaries, is $715 \mathrm{~km}$, while the corresponding area analyzed is about $650 \mathrm{~km}^{2}$ ! In order to perform flood wave management of this system besides the bathymetry of the Danube, the tributaries and the corresponding flood plains, the DTM was needed to include the potential retention storages, so the total area covered by the DTM is over 7000 $\mathrm{km}^{2}$ !

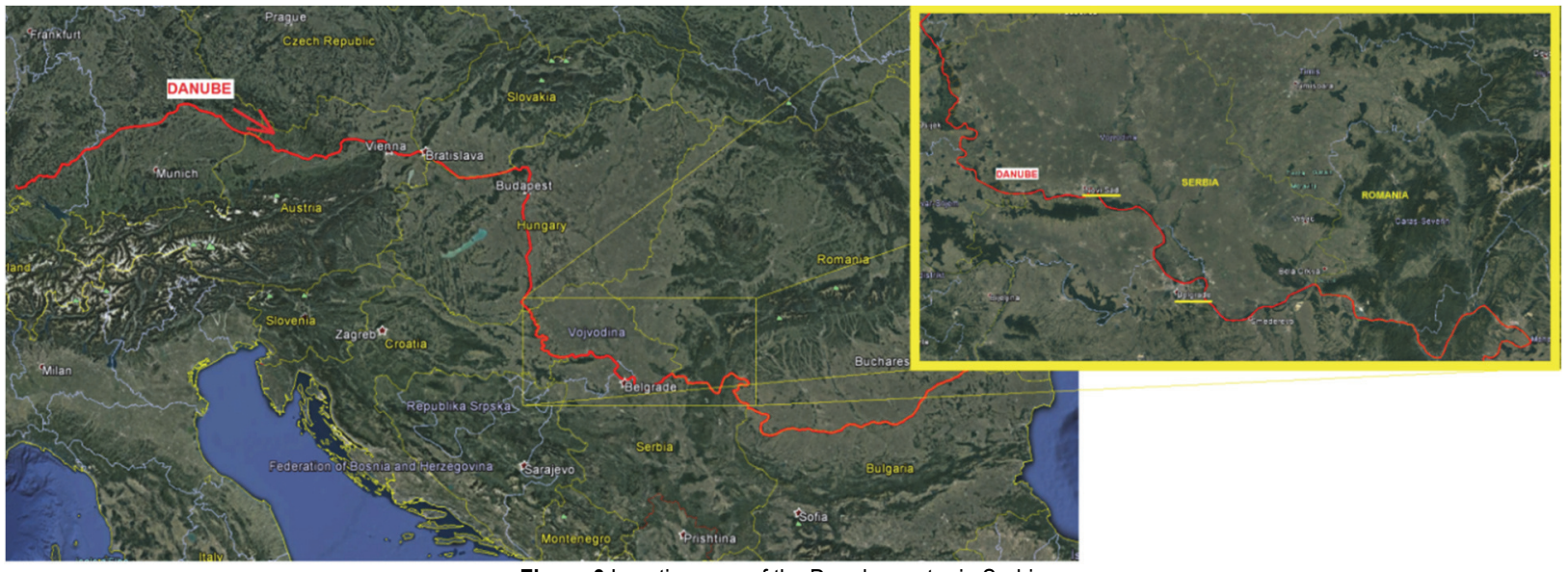

Figure 3 Location map of the Danube sector in Serbia

\section{METHODOLOGY OF THE DEVELOPMENT OF THE 1D/2D HYDRAULIC MODELS}

The methodology for the development of hydraulic models consists of three stages/elements:

- Preparation of topographic input data for the hydraulic model, DTM generation.

- Efficient software package for open channel flow simulation based on which roughness coefficients
(Manning's - n) for each designed section (1D model) or cell (2D model) are specified, and

- Obtained data validation modelling.

\subsection{First Stage - DTM Generation}

The first stage in the development of the model includes generation of a digital terrain model (DTM). One of the most challenging tasks for an engineer is to provide 
input data required for any hydraulic analysis. It can be therefore said that the quality of the entire study significantly depends on the quality of the input data.

Airborne laser scanning or terrestrial scanning of the terrain from a moving vehicle was used in the study. Today LiDAR scanning system is one of the most advanced techniques used in surveying and developing of topographic plans and $3 \mathrm{D}$ terrain models. LiDAR is the result of integration of three techniques into one system. The combination allows definition of the laser point position on the surface with high accuracy.

The technique is based on the acquisition of three different data sets. The sensor position is defined by GPS (Global Positioning System) with stage measurements in a relative kinematical regime while orientation is defined by using IMU (inertial measurement unit). The last element is a laser scanner which emits 36000 points (and more) per second. Infrared beam is directed towards the earth's surface and reflected back to the sensors that is, the scanner emits high-frequency pulses reflected from the earth's surface back to the device.

Technical specifications of the laser system "MKII Topeye" presented in the article by Sole et al. [23], which system was also capable of scanning multiple echoes (not only the first and the last pulse), and the mobile scanning system "MLS Riegl VUX-1" used for the purposes of this study are compared in order to illustrate advances in these systems in the last years.

Table 1 LiDAR system characteristics

\begin{tabular}{|c|c|c|}
\hline & Laser Topeye MKII & MLS Riegl VUX-1 \\
\hline Laser type & $\begin{array}{c}\text { Fiber Laser with } 2 \\
\text { channels }\end{array}$ & Multi pulse Laser \\
\hline Scanner type & Palmer Scanner & $\begin{array}{c}\text { Fast Rotating } \\
\text { Mirror }\end{array}$ \\
\hline Scan frequency & $50 \mathrm{kHz}$ & $550 \mathrm{kHz}-50 \mathrm{kHz}$ \\
\hline Pulse length & $4 \mathrm{~ns}$ & $0.02 \mathrm{~ns}$ \\
\hline Range & $60-1000 \mathrm{~m}$ & $3-5000 \mathrm{~m}$ \\
\hline $\begin{array}{c}\text { Minimum } \\
\text { measurement density }\end{array}$ & $\begin{array}{c}4 \text { points } \\
\text { measurement } / \mathrm{m}^{2}\end{array}$ & $\begin{array}{c}30.000-550.000 \\
\text { meas. } / \mathrm{sec}\end{array}$ \\
\hline $\begin{array}{c}\text { Alti metrical accuracy } \\
\text { in open areas }\end{array}$ & $\pm 0,15 \mathrm{~m}$ & $\pm 0,01 \mathrm{~m}$ \\
\hline Planimetric accuracy & $\pm 0,30 \mathrm{~m}$ & $\pm 0,01 \mathrm{~m}$ \\
\hline
\end{tabular}

LiDAR scanning is performed in motion and the system can be mounted on a vehicle for terrestrial scanning of objects such as roads, levees and similar line infrastructure buildings or on an aircraft for aerial scanning which is a more detailed but also more costly option due to the plane or helicopter rental. It is recommended based on the study of the Danube River hydraulic model that point density for LiDAR terrestrial scanning from a moving vehicle and aerial scanning is $0.2 \mathrm{~m}$ and $5 \mathrm{~m}$, respectively.

LiDAR point cloud density is a function of the number of laser pulses and the speed of the vehicle. The data is collected on the position of points on the earth's surface with the density of up to 100 points per $\mathrm{m}^{2}$ (Figs. 4 and 5). The advantage of the LiDAR system is the possibility of collecting points after the reflection from the earth's surface and passing through a tree crown, for instance. Specifically, LiDAR beams can penetrate through vegetation cover (forests and other vegetation) and generate $x, y, z$ point data in the vicinity and on the earth's surface.
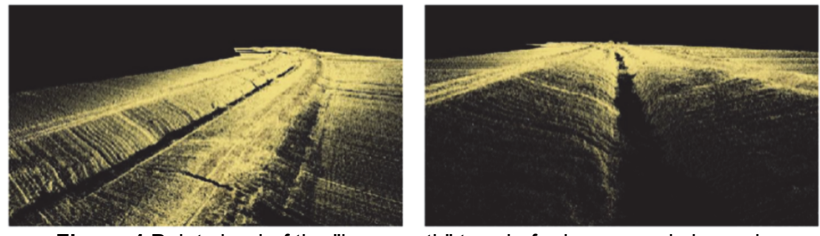

Figure 4 Point cloud of the "bare earth" terrain for levees and channels

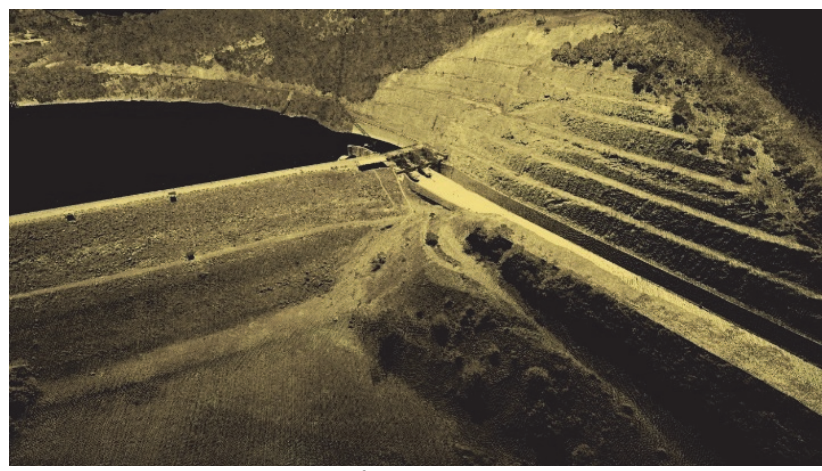

Figure 5 Point cloud of the scanned dam with a spillway

DSM (Digital Surface Model) is first generated from laser scanning followed by the creation of DTM by filtering from the generated DSM using special algorithms.

Both images are shown in the same coordinate system simultaneously to combine the point clouds generated from airborne and terrestrial scanning. The two data sets make a combination which can produce vertical discrepancies of up to $20 \mathrm{~cm}$ where the two images overlap. A common software package ArcGIS cannot be used to cover the entire surveyed area due to the limited memory. Here, several tens or hundreds of millions of scanned points were studied. The most appropriate solution to the issue in flood modelling appears to be generation of certain overlapping sections (areas) that would be automatically sequenced by the software, which was performed in this study.

LiDAR data provide essential support to the flood and flood risk analyses and hydraulic modelling though LiDAR system is incapable of providing any information on underwater topography. Since acquisition of data on a river bed is not possible, it is necessary to apply echosonar bathymetric measurements. Continuous improvement in technologies resulted in the development of bathymetric LiDAR capable of generating data on bottoms of shallow streams, ponds and lakes, which is a new method of surveying inundations and pounded areas.

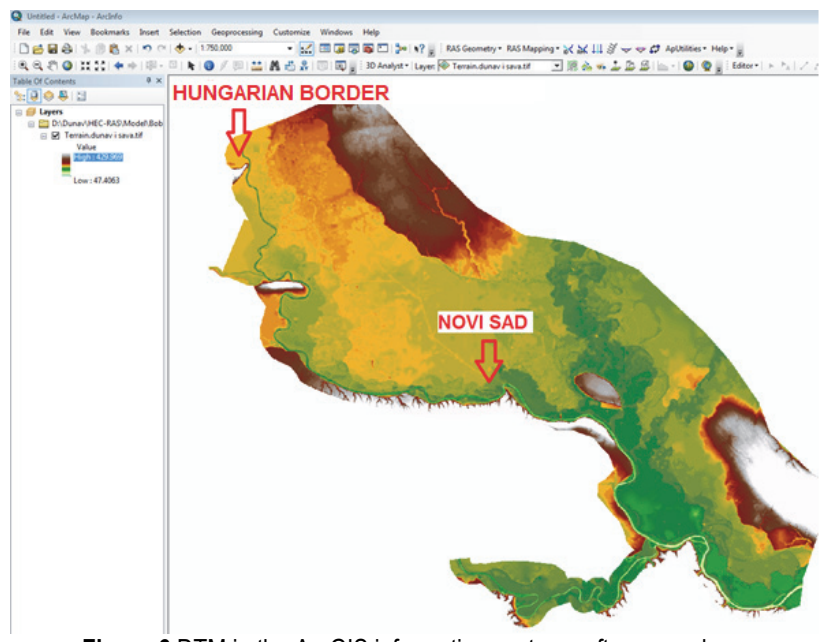

Figure 6 DTM in the ArcGIS information system software package 
As a final result, a DTM of the main watercourse with inundations and potential retention ponds was generated for further hydraulic analysis (Fig. 6). The total area covered by the DTM is over $7000 \mathrm{~km}^{2}$.

\subsection{Second Stage - Hydraulic Model}

Hydraulic model required for land planning and flood management was developed following the acquisition and processing of topographic and hydrological data. Software package HEC-RAS 5 (Hydrologic Engineering CentreRiver Analysis System - US Army Corps of Engineers) was used to develop the hydraulic model. Software version (May 2015) capable of 1D (present versions) and 2D modelling was used.

It is now possible to perform $1 \mathrm{D}$ and $2 \mathrm{D}$ modelling with unsteady flow, complete Saint-Venant equations or diffusion wave equation as well as the combination of $1 \mathrm{D}$ and $2 \mathrm{D}$ modelling. This version allows $2 \mathrm{D}$ modelling of possible retention ponds leading to a more realistic presentation of floodplains. 2D modelling of retention ponds is performed by the input of retention parameters in the same way as in 1D modelling of potential inundations. In the river sections where significant changes in terms of 1D flow occur, cell displacements, additions and deletions are required. The structured network is transformed into an unstructured network by cell displacements, additions and deletions within a 2D polygon.

The 2D model produces calculation mesh by Delaunay triangulation followed by the generation of the Voronoi diagram. Trigonometric grid of triangles is shown in black whereas cell fronts in red colour are constructed as bisectors of triangle sides. The method is analogous to the Thiessen polygon method for rainfall calculation.

The coupled 1D/2D model was mainly used for the river sections with significant changes in flow directions in the main channel and inundations. Special attention must be given to coupled $1 \mathrm{D} / 2 \mathrm{D}$ model that must be taken when drawing in boundary contours between the cross section and 2D mesh. The contour line should follow a "zigzag" cross section line according to the streamlines path. It is very important to match Manning's coefficients of roughness in the mesh sections to the coefficients in the cross section to avoid flow disturbances. The results of the 2D flow simulation are shown in Fig. 7.

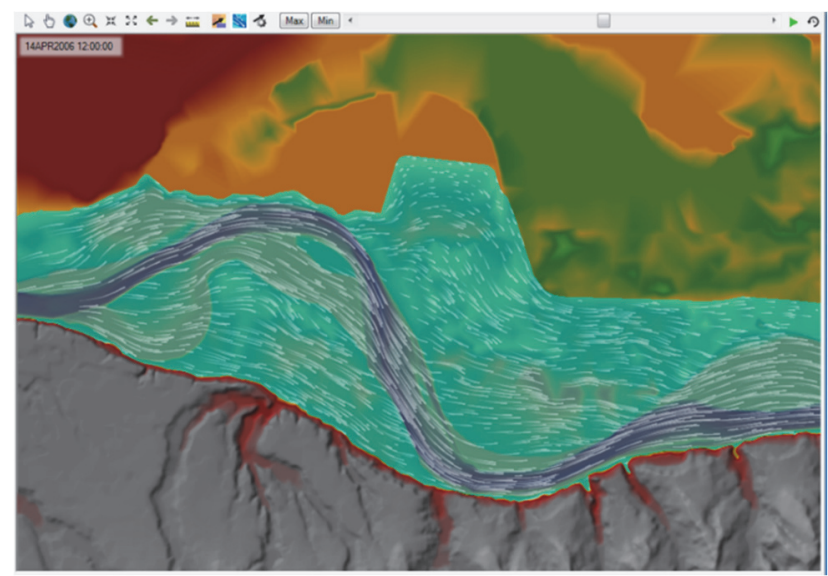

Figure $72 \mathrm{D}$ simulation of the main (minor) and inundation (major) flows in the Danube River section

\subsection{Third Stage - Hydrological Analysis}

Hydrological data collected for the stages and flows are required for calibration and validation of the hydraulic model. Continuous measurements on hydrometric profiles in Central Europe (the rivers Danube, Tisa, Sava, ...) started after the disastrous floods in 1876.

Since the available surveys of cross sections of the Danube River date from 2014 it was necessary to collect and process hydrometric data from the year (2015) closest to the major flood. Model calibration was performed gradually starting from short sections (from one hydrological station to another). Processed hydrological data is required as boundary conditions on upstream and downstream ends of each section.

In order to apply the hydraulic model on various flood waves it is necessary to perform verification using data corresponding to a known flood wave from recent years while the parameters (river bed morphology and vegetation) are still unaltered. The flood wave of the 2006 spring was used to validate the model, which was very close to the $1 \%$ flood in terms of water stage and showed extremely unsteady characteristics when compared to some other flood waves (1965) due to rapid increase and decrease of its peak.

The outcome of the study described in the article, among others, is the definition of the procedure for providing sufficient accuracy (up to several centimetres) in the flood wave calculations. In addition, the calculations could be accomplished for only 2-3 hours, allowing to serve their purpose. This is especially important when simulating propagation of the coming flood wave in order to take proper decision instantly in order to reduce the potential damage caused by flooding.

\section{RESULTS AND DISCUSSIONS}

New "Methodology of hydraulic model development" has been established based on this study which is modified compared to the methodology proposed by Prafulla [20]. Meanwhile, new software tools such as the HEC RAS 5 for 2D flow simulation have been developed. Additionally, the algorithm in the study of Prafulla (2015) is suitable for rather small catchments since the flood wave was calculated based on the rainfall-runoff relation using HECHMS modelling. However, this study is focused on lowland rivers with the methodology adjusted accordingly. Fig. 8 on the following page shows the methodology developed to create hydraulic model of unsteady $1 \mathrm{D} / 2 \mathrm{D}$ flow as a base for specifying measures and strategies for the development of the flood management plan for lowland rivers.

An additional method was developed to specify relevant flood stage (design flood) which is used to determine levee crest elevation. In Serbia the flood of 1\% probability is chosen as design flood, while crest elevation of the dike is set to be $1,20 \mathrm{~m}$ above the $1 \%$ water level (Fig. 9). Results of the study with the verified hydraulic model of the Danube River with its tributaries (the Drava, Tisa, Sava and Morava rivers) indicate the maximum difference between the measured and computed stages of $5-10 \mathrm{~cm}$ (Fig. 10). 


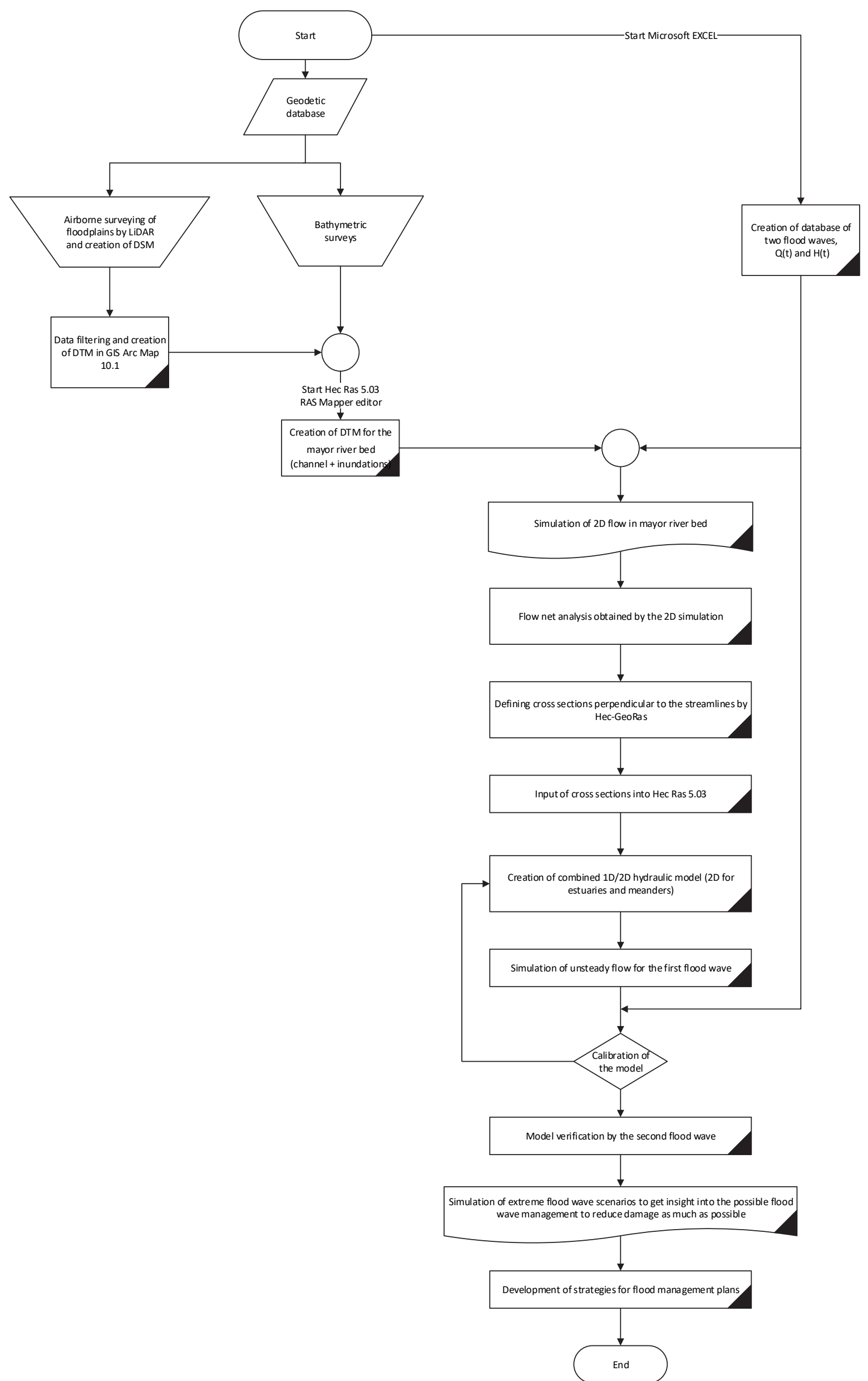

Figure 8 Algorithm of developing unsteady 1D/2D hydraulic model for defining strategies and measures of flood management plans in case of large lowland rivers 


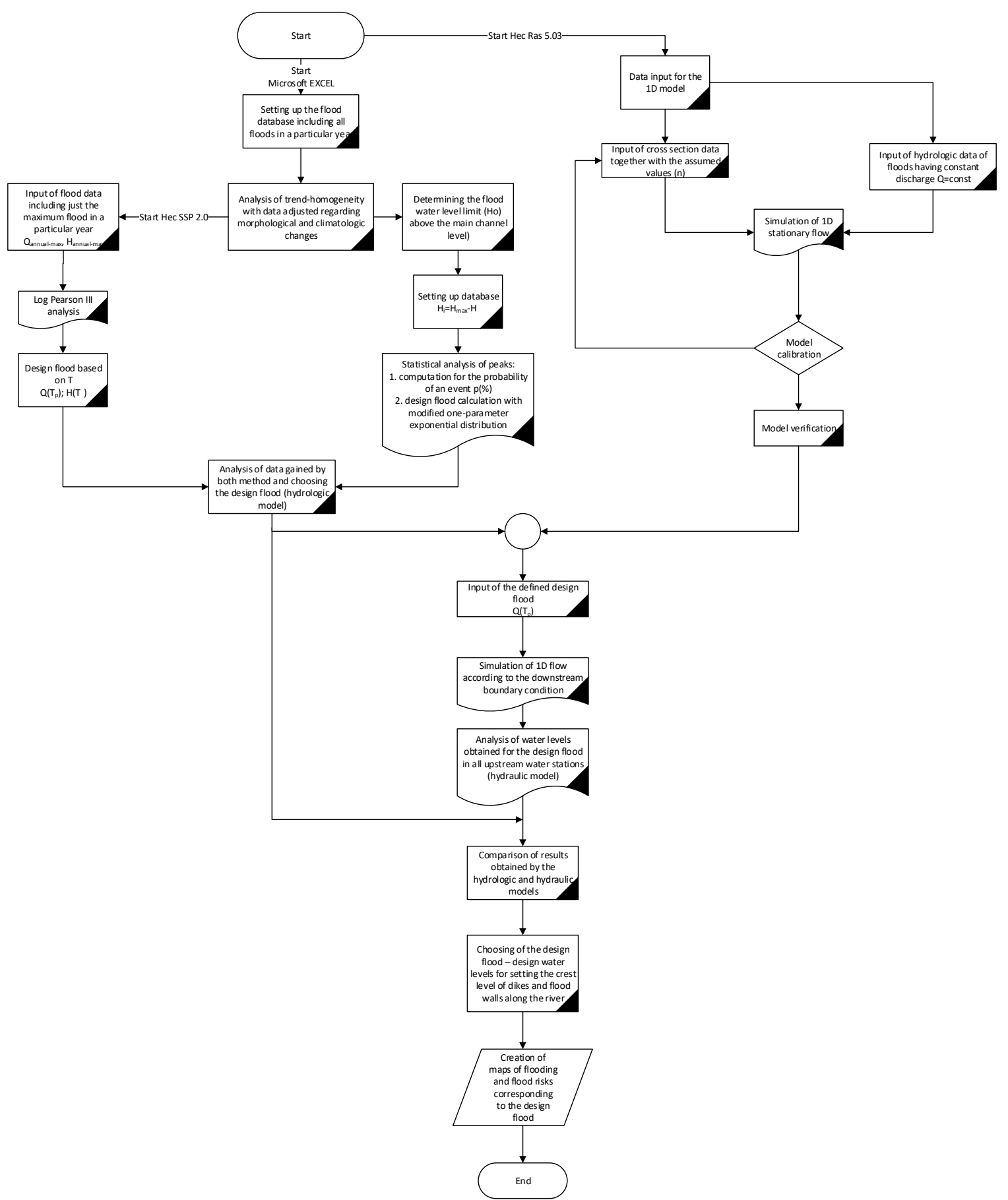

Figure 9 Algorithm of determining the design flood based on which the elements of flood defence (flood dikes, flood walls) are designed in case of large lowland rivers

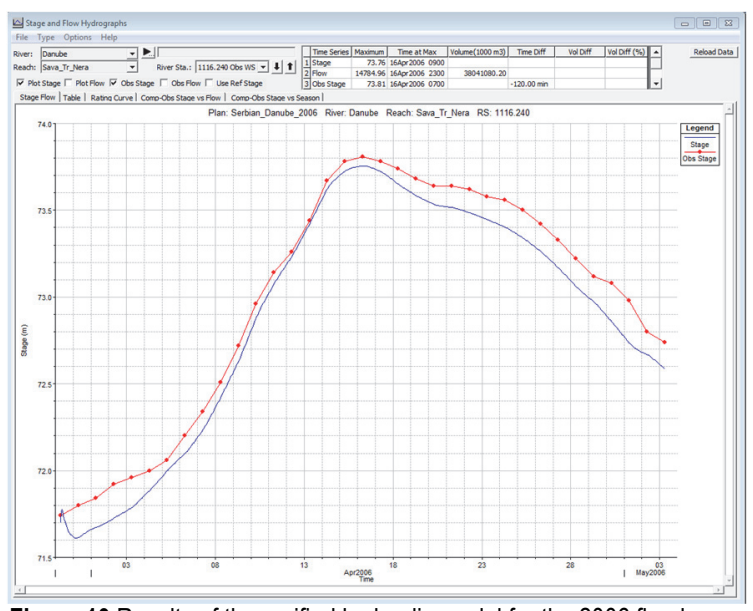

Figure 10 Results of the verified hydraulic model for the 2006 flood wave simulation at the Smederevo hydrolog station (the Danube River)

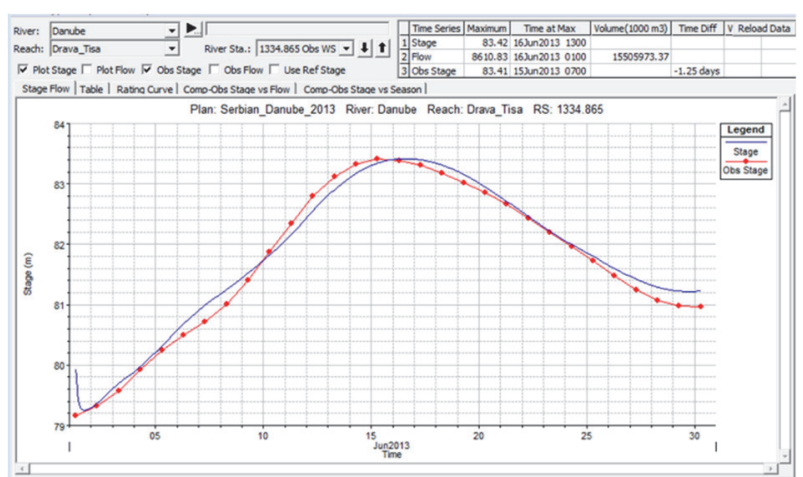

Figure 11 Results of the 2013 flood wave simulation at the Vukovar hydrological station (the Danube River)

We can consider these results satisfactory and say that the model was successfully verified for such a complex 
model of the Danube with tributaries, and taking into account that the bathymetry is from 2014 .

The model was calibrated for the 2015 (May and June) flood wave and validated for the 2006 (April and May) flood wave, while Fig. 11 shows the results of the 2013 flood wave simulation with computational time steps of 1 hour. The Vukovar hydrological station (Croatia) is located approximately $400 \mathrm{~km}$ upstream to the Đerdap Dam 1 representing the downstream boundary condition of the model.

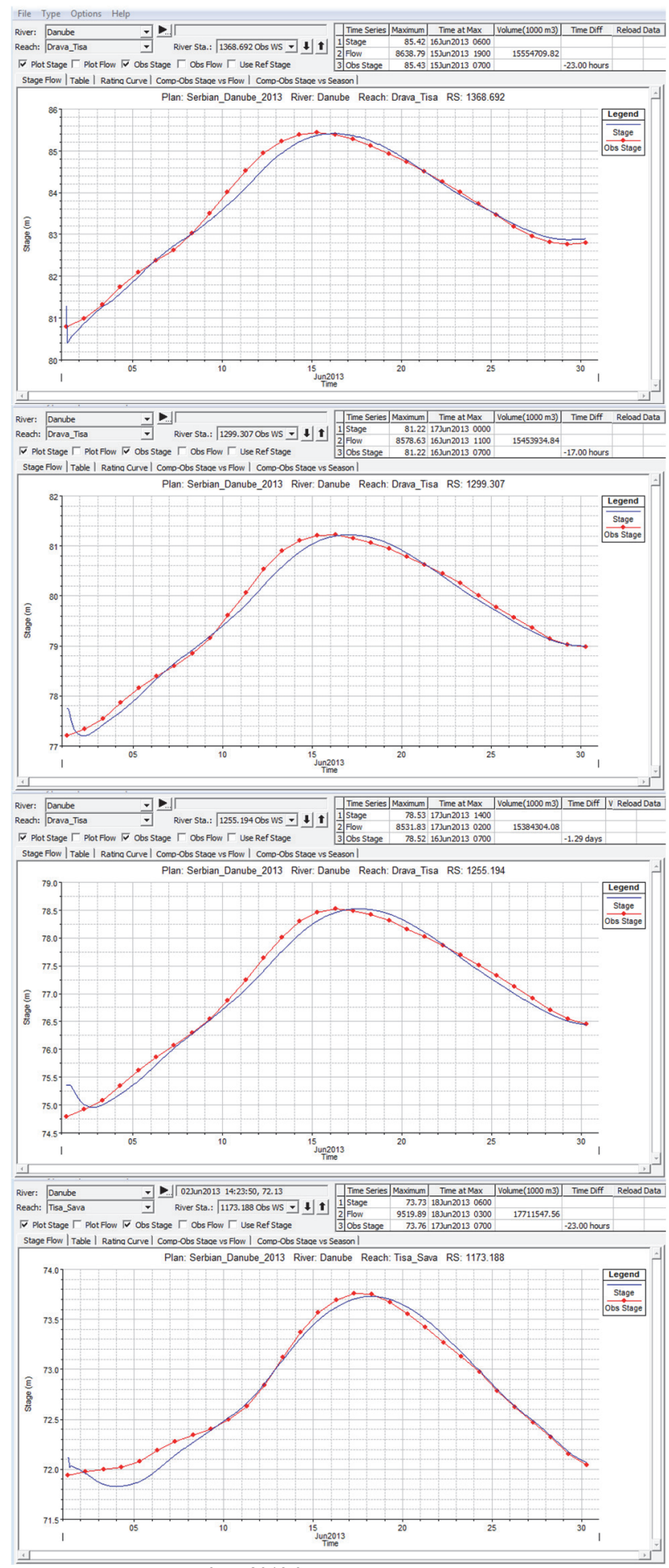

Figure 12 Results of the 2013 flood wave simulation at Bogojevo, Backa Palanka, Novi Sad and Zemun hydrological stations
Fig. 12 shows the results of the 2013 flood wave simulation on other relevant hydrological stations with maximum difference between the measured and computed stages up to $\pm 3 \mathrm{~cm}$.

The results of this analysis have shown that the frequency of water stage measurements needs to be at least 2-4 times a day, while according to the current practice it is measured just once a day at 7:00. Specifically, this practice leads to certain time shifts in the measured and computed water stage values visible in Figs. 9 and 10.

Single run of $1 \mathrm{D} / 2 \mathrm{D}$ unsteady flow simulation in case of the Danube hydraulic model developed for this study having total length of tributaries of $715 \mathrm{~km}$ required approximately 90 minutes which is short enough to serve their purpose. The following table lists hardware specifications needed to achieve mentioned computational time:

Table 2 Available system and hardware specifications for 1D/2D simulations

\begin{tabular}{|c|c|}
\hline Processor & $2.6(3.5) \mathrm{GHz}$ i7 \\
\hline CPU & 4 core \\
\hline RAM & 16 GB DDR4 \\
\hline Storage & 512 SSD \\
\hline Operating system & Windows 10 (64-bit) \\
\hline
\end{tabular}

\section{CONCLUSIONS}

To reduce "flood risk with adverse effects" it is necessary to manage flood wave and specify measures for mitigation of adverse effects through simulations of different events. This requires a hydraulic model of sufficient accuracy which can provide precise assessment of the effect of any measure on peak discharge.

The objective of the study was to define this methodology providing sufficient accuracy to the hydraulic model of flood wave propagation in case of large lowland rivers, requiring acceptable short calculation time.

Despite efficiency, 1D models run in problems when modelling meandering lowland rivers with retention basins. In response to that combination of $2 \mathrm{D}$ hydraulic models with 1D models in flood wave mitigation, calculations came up and became standard in the recent years $[1,6,10]$. Prerequisite of an efficient hydraulic model is creation of DTM, which was a daunting task before the appearance of the LiDAR technology which could provide the accuracy required by $2 \mathrm{D}$ models.

Recommendation coming from the outlined hydraulic model of the Danube River is that mesh density of $0.2 \mathrm{~m}$ and $5.0 \mathrm{~m}$ needs to be applied if survey is performed by a moving vehicle or a plane, respectively. According to NEAA standards it will provide data accuracy of QL2. The results of both surveys from the moving vehicle and the airplane are presented in the same coordinate system, which produces vertical discrepancy of about $20 \mathrm{~cm}$ in the overlap domain. Due to the limited memory, ArcGIS often cannot handle the complete data set of the surveyed area consisting of up to several hundred million points. This can be overcome in case of flood wave simulations by generating overlapping domains alternatively selected and used by the corresponding software. The approach proved itself successful, thus it has been adopted in the current study. 
Based on the experience with recorded floods that occurred during the last 150 years (1876-2017) and on the experience gained on the Danube River model with its tributaries presented in this paper as well as on the results of recent studies outlined in the work of Turner B. A. [25], accuracy of the DTM used in hydraulic models of large lowland rivers needs to be at least $\pm 10 \mathrm{~cm}$. This refers to "large" hydraulic models of lowland streams. The studied model of the Danube with its tributaries is $715 \mathrm{~km}$ long river flow with the low and high stage difference of almost $9 \mathrm{~m}$.

\section{REFERENCES}

[1] Abu-Aly, T. R., Pasternack, G. B., Wyrick, J. R., Barker, R., Massa, D., \& Johnson T. (2014). Effects of LiDAR-derived, spatially distributed vegetation roughness on twodimensional hydraulics in a gravel-cobble river at flows of 0.2 to 20 times bankfull. Geomorphology, 206, 468-482. https://doi.org/10.1016/j.geomorph.2013.10.017

[2] An, H., Yu, S., Lee, G., \& Kim, Y. (2015). Analysis of an open source quadtree grid shallow water solver for flood simulation. Quarternary International, 384, 118-128. https://doi.org/10.1016/j.quaint.2015.01.032

[3] APFM - Associated Programme on Flood Management. (2016). The role of Land-use Planning In Flood Management - A Tool for Integrated Flood Management. World Meteorological Organization.

[4] Bales, J., Wagner, C., Tighe, K., \& Terziotti, S. (2007). LiDAR Derived Flood Inundation Maps for Real Time Flood Mapping Applications, Tar River Basin, North Carolina. Scientific Investigations Report, 2007-5032, U.S. Geological Survey, Reston, Virginia. https://doi.org/10.3133/sir20075032

[5] Camorani, G., Castellarin, A., \& Brath, A. (2005). Effects of land-use changes on the hydrologic response of reclamation systems.Physics and Chemistry of the Earth, 30, 561-574. https://doi.org/10.1016/j.pce.2005.07.010

[6] Costabile, P. \& Macchione F. (2015). Enhancing river model set-up for 2-D dynamic flood modelling. Environmental Modelling \& Software, 67, 89- 107. https://doi.org/10.1016/j.envsoft.2015.01.009

[7] Dasallas, L., Yeonsu, K., \& Hyunuk, A. (2019). Case Study of HEC-RAS 1D-2D Coupling Simulation: 2002 Baeksan Flood Event in Korea. Water, 11. https://doi.org/10.3390/w11102048

[8] Di Baldassarre, G., Kooy, M., Kemerink, J. S., \& Brandimarte, L. (2013). Towards understanding the dynamic behaviour of floodplains as human-water systems. Hydrology and Earth System Sciences, 17, 3235-3244. https://doi.org/10.5194/hess-17-3235-2013

[9] Fohrer N., Haverkamp S., Eckhardt K., Frede H.G. (2001). Hydrologic response to landuse changes on the catchment scale. Physics and Chemistry of the Earth (B), 26, 577-582. https://doi.org/10.1016/S1464-1909(01)00052-1

[10] Gichamo, T. Z., Popescu, I., Jonoski, A., \& Solomatine, D. (2012). River Cross-section extraction from the ASTER global DEM for flood modelling. Environmental Modelling \& Software, 31, 37-46. https://doi.org/10.1016/j.envsoft.2011.12.003

[11] Gocic, M., Shamshirband, S., Razak, Z., Petkovic, D., Sudheer, C., \& Trajkovic, S. (2016). Long-term precipitation analysis and estimation of precipitation concentration index using three support vector machine methods. Hindawi Publishing Corporation, Advances in Meteorology, 11. https://doi.org/10.1155/2016/7912357

[12] Guha-Sapir, D., Hoyois, P., \& Below, R. (2016). Annual Disaster Statistical Review 2015: The Numbers and Trends.
Centre for Research on the Epidemiology of Disasters, Brussels.

[13] Guha-Sapir, D., Hoyois, P., Wallemacq, P., \& Below, R. (2017). Annual Disaster Statistical Review 2016: The Numbers and Trends. Centre for Research on the Epidemiology of Disasters, Brussels.

[14] Hall, J., Arheimer, B., Borga, M., Brázdil, R., Claps, P., Kiss, A., Kjeldsen, T. R., Kriauciuniene, J., Kundzewicz, Z. W., Lang, M., Llasat, M. C., Macdonald, N., McIntyre, N., Mediero, L., Merz, B., Merz, R., Molnar, P., Montanari, A., Neuhold, C., Parajka, J., Perdigão, R. A. P., Plavcová, L., Rogger, M., Salinas, J. L., Sauquet, E., Schär, C., Szolgay, J., Viglione, A., \& Blöschl, G. (2014). Understanding flood regime changes in Europe: a state-of-the-art assessment. Hydrology and Earth System Sciences, 18, 2735-2772. https://doi.org/10.5194/hess-18-2735-2014

[15] Kolaković, S. S. (2017). Flood management of lowland rivers in the stream of the Danube river through Serbia. Doctoral dissertation, Faculty of Technical Sciences, University of Novi Sad, Serbia.

[16] Kolaković, S. S., Fabian, Đ., Kovacs, S., Budinski, LJ., \& Stipić, M. (2016). Exploitation of documented historical floods for achieving better flood defense. Hindawi Publishing Corporation, Advances in Meteorology, 9. http://dx.doi.org/10.1155/2016/2317252

[17] Li, Z., Liu, W. Z., Zhang, X. C., \& Zheng, F. L. (2009). Impacts of land use change and climate variability on hydrology in an agricultural catchment on the Loess Plateau of China. Journal of Hydrology, 377, 35-42. https://doi.org/10.1016/j.jhydrol.2009.08.007

[18] Meesuk, V., Vojinovic, Z., Mynett, E. A., \& Abdullah, F. A. (2015). Urban flood modelling combining top-view LiDAR data with ground-view SfM observations. Advances in Water Resources, 75, 105-117. https://doi.org/10.1016/j.advwatres.2014.11.008

[19] Mirkov, N. (1924). Navigable rivers and canals. Vojvodina 1924, Novi Sad, Serbia.

[20] Prafulla, K. P. (2015). Modelling of Floodplain Using Recent Technology. European Journal of Advances in Engineering and Technology, 2, 23-28.

[21] Sampson, C. C., Fewtrell, J. T., Duncan, A., Shaad, K., Horritt, S. M., \& Bates, D. P. (2012). Use of terrestrial laser scanning data to drive decametric resolution urban inundation models. Advances in Water Resources, 41, 1-17. https://doi.org/10.1016/j.advwatres.2012.02.010

[22] Shen, D., Wang, J., Cheng, X., Rui, Y., \& Ye, S. (2015). Integration of 2-D hydraulic model and high-resolution lidar-derived DEM for floodplain flow modeling. Hydrology and Earth System Sciences, 19, 3605-3616. https://doi.org/10.5194/hess-19-3605-2015

[23] Sole, A., Giosa, L., Nole, L., Medina, V., \& Bateman, A. (2008). Flood risk modelling with LiDAR technology. Flood Recovery, Inovation and Response, WIT press, Southampton, UK, 27-36. https://doi.org/10.2495/FRIAR080031

[24] Tomer, M. D. \& Schilling, K. E. (2009). A simple approach to distinguish land-use and climate-change effects on watershed hydrology. Journal of Hydrology, 376, 24-33. https://doi.org/10.1016/j.jhydrol.2009.07.029

[25] Turner, B. A., Colby, D. J., Csontos, M. R., \& Batten A. (2013). Flood Modeling Using a Synthesis of Multi-Platform LiDAR Data. Journal Water, 5, 1533-1560. https://doi.org/10.3390/w5041533

[26] Viero, P. D., Roder, G., Matticchio, B., Defina, A., \& Tarolli, P. (2019). Floods, landscape modifications and population dynamics in anthropogenic coastal lowlands: The Polesine (northern Italy) case study. Science of the Total Environment, 651, 1435-1450. https://doi.org/10.1016/j.scitotenv.2018.09.121

[27] Vozinaki, A. E. K., Morianou, G. G., Alexakis, D. D., \& Tsanis, K. I. (2017). Comparing 1D and combined 1D/2D 
hydraulic simulations using high-resolution topographic data: a case study of the Koiliaris basin, Greece. Hydrological Sciences Journal, 62(4), 642-656. https://doi.org/10.1080/02626667.2016.1255746

[28] Whitfield, P. (2012). Floods in future climates: a review. Journal of Flood Risk Management, 5, 336-365. https://doi.org/10.1111/j.1753-318X.2012.01150.x

[29] Wooldridge, S., Kalma, J., \& Kuczera, G. (2001). Parameterisation of a simple semidistributed model for assessing the impact of land-use on hydrologic response. Journal of Hydrology, 254, 16-32. https://doi.org/10.1016/S0022-1694(01)00489-9

[30] Zope, P. E., Eldho, T. I., \& Jothiprakash, V. (2016). Impacts of land use-land cover change and urbanization on flooding: a case study of Oshiwara River Basin in Mumbai, India. Catena, 145,142-154. https://doi.org/10.1016/j.catena.2016.06.009

[31] Zope, P. E., Eldho, T. I., \& Jothiprakash V. (2017). Hydrological impacts of land use-land cover change and detention basins on urban flood hazard: a case study of Poisar River basin, Mumbai, India. Natural Hazards, 87, 1267-1283. https://doi.org/10.1007/s11069-017-2816-4

\section{Contact information:}

Slobodan KOLAKOVIĆ, Assist. Prof.

Department of Civil Engineering,

Faculty of Technical Sciences, University of Novi Sad,

Trg Dositeja Obradovica 6, 21000 Novi Sad, Serbia

E-mail: kolakovic.s@uns.ac.rs

Srđan KOLAKOVIĆ, Full Prof.

(Corresponding author)

Department of Civil Engineering,

Faculty of Technical Sciences, University of Novi Sad,

Trg Dositeja Obradovica 6, 21000 Novi Sad, Serbia

E-mail: kolak@uns.ac.rs

Julius FABIAN, Full Prof.

Department of Hydraulic, Water Resources and Environmental Engineering,

Faculty of Civil Engineering Subotica, University of Novi Sad,

Kozaracka 2/a, 24000 Subotica, Serbia

E-mail: julius@gf.uns.ac.rs

Goran JEFTENIĆ, Assistant

Department of Civil Engineering,

Faculty of Technical Sciences, University of Novi Sad,

Trg Dositeja Obradovica 6, 21000 Novi Sad, Serbia

E-mail: goran.jeftenic@uns.ac.rs

Slaviša TRAJKOVIĆ, Full Prof.

Faculty of Civil Engineering and Architecture,

University of Nis,

A. Medvedeva 14, $18000 \mathrm{Nis}$, Serbia

E-mail: slavisa.trajkovic@gaf.ni.ac.rs 